\title{
American Soft Power Through Hollywood Superhero Movies: The Case of the Trilogy of Captain America
}

\author{
Lalita Suwankaewmanee ${ }^{1}$ \\ ${ }^{1}$ Department of English and Linguistics, Thammasat University, Bangkok, Thailand \\ Correspondence: Lalita Suwankaewmanee, Department of English and Linguistics, Thammasat University, \\ Bangkok, Thailand. E-mail: lalita.s@hotmail.com
}

Received: May 10, 2021 Accepted: June 15, 2021 Online Published: June 23, 2021

doi:10.5539/ells.v11n3p1 URL: https://doi.org/10.5539/ells.v11n3p1

\begin{abstract}
The Captain America trilogy exemplifies American ideals: individuality, democracy, liberty, equality, and patriotism through the life and identity of its protagonist Steve Rogers. From the blatant display of American cultures to American values to the artistic imitation of American policies, the Captain America trilogy incorporates all mentioned elements and presents the world the compelling stories where heroes are created, sacrifices are made, damages are done - all for the protection of humanity. As the curtain closes, superheroes always emerge as the saviors - to all. The assertion of power, as the trilogy demonstrates, is no longer through the brutal force of military power but wielded through soft power, namely culture, values, and policies. Only through careful analysis of the storyline, character traits, dialogues, and images, one may discover hidden messages in the art that imitates life. As stated by Joseph Nye (1990), a political scientist, "the best propaganda is not propaganda".
\end{abstract}

Keywords: Hollywood superhero movies, the trilogy of Captain America, American soft power, popular culture, the source of power, American culture, American values, American foreign policies

\section{Introduction}

The new face of power is called 'soft power.' This term was coined and developed by Joseph Nye in 1989. It is a power of persuasion and attraction. It arises from a country's culture, political values, and policies. Nye (2004) stated that soft power is one source of influence. Many countries in the world have shifted their interest from hard power to soft power and invested their money in culture to help them create soft power. The country which displays a high level of soft power is the United States of America (USA) and its soft power is very distinguished on the global stage. Hollywood is a good example to explain how soft power is created and its influence spread. Other than the entertainment industry, technology and education are counted as means to produce soft power.

Power today is less tangible and coercive among advanced democracies than it was in the past (Nye, 2004). Hollywood is one of the significant soft power tools which the USA uses to influence people and the USA produces and exports numerous movies around the world every year. Hollywood movies make billions of dollars every year with an increasingly growing number. However, producing movies in Hollywood studios could be a challenging and bureaucratic process as the guideline of producing certain types of movies required interference from the government. David L. Robb (2004) argued that Hollywood has always been influenced by the elite and institutions of the government. The Central Intelligence Agency (CIA) and the Department of Defense (DoD) are revealed in engaging in programs to influence the content of the movies produced by Hollywood studios (Secker \& Alford, 2017). Tarabay (2014), an Aljazeera's reporter, interviewed Phil Strub, the Pentagon's entertainment-liaison officer, about the military support for Hollywood movies. Strub has been the Pentagon's liaison officer in Hollywood for more than 25 years. His name has appeared in the after credits of many movies; special thanks for him were reserved for him by many notable movie producers. The Pentagon has a long history of censoring and financing Hollywood films by providing military equipment or military experts for film productions. The way Hollywood movies narrate the story can lead to the control of global societies and the power dynamics existed since the stories do reflect real life (Kellner, 2010).

Noting the importance of the film industry, since the year 2001, after the September $11^{\text {th }}$ incident, superhero movies have been resurrected by Hollywood to much more popular mainstream mass consumption. This type of movie also produces a massive revenue stream. Comic superhero characters are portrayed in a number of films 
and several movie franchises. Superhero films are particularly relevant to the representation of the September 11 incident in the USA as they demonstrate heroic responses to a crisis. Superhero films model leadership styles and visually present the assumed proper relations between leaders and their people, as well as between an individual and a community. Finally, these movies came to define notions of sacrifice and service and explore the possibility of agency against a backdrop of fate and determination (Kord \& Krimmer, 2011).

The Pentagon also embraces the superhero movie Captain America: The First Avenger (2011) which was inspired by a real-world event, World War II. Steve Rogers, a weak man who was rejected from the military, was chosen to undergo a special treatment to create a super-soldier by the U.S. government. He was injected with a serum created by a scientist and became the super-soldier Captain America who was stronger and a symbolic representation of the USA. Captain America's transformation was used as a metaphor for the United States during World War II. The US wanted to imply that the country is not a warlike nation, but the reason that USA was involved with the war is because of the moral quest and that it was 'the right thing' to do. Similarly, Rogers felt the same as he was weak and did not like bullies. At the end of the movie Captain America sacrificed himself protecting the US from the leader of Hydra, the antagonist, that wanted to attack the United States - this reinforces this metaphor. Captain America was supported by the U.S. military for this exact reason (Secker \& Alford, 2017). There are two more movies of Captain America which are Captain America: The Winter Soldier (2014) and Captain America: Civil War (2016). Captain America movies are a form of popular culture which was exported from Hollywood to millions of audiences around the world and Captain America movies consist of many hidden political messages. Furthermore, the movies and the Captain America character represent many aspects of American values such as democracy, individualism, liberty, equality, and patriotism - with patriotism as the strongest representation. Kellner (1995) said that the way Hollywood narrates the stories can have an impact on societies as it is produced based on real life issues so people can relate to themselves in these stories. In addition, since the resurrection of superhero movies after 9/11, Hollywood keeps producing superhero movies until now and this type of movie captures the wider audience; each generation is fascinated by and admires the superhero characters. Captain America movies and other Hollywood movies are exported to people from all over the world. These audiences are not aware that they may be influenced by American soft power through these movies, especially for children and young adults as they are easily influenced. We now live in the world where geopolitics and culture are being given by the major power countries. Popular media is used as a form of propaganda to attract people and promote themselves. Nowadays, people can readily access media and it is even easier for them to be influenced (Redmond, 2017). Therefore, when the audiences consume media, especially movies, apart from finding them entertaining, they should be conscious and think about the hidden details that may influence their opinions.

\section{Research Question}

Fun, exciting, and entertaining Captain America: The First Avenger (2011), Captain America: The Winter Soldier (2014), and Captain America: Civil War (2016) stress that the resources of American soft power with the focus on America value of Patriotism. Utilizing soft power as its principal theoretical frameworks, this study therefore aims to address the following research question: How does the trilogy of Captain America movies reflect three resources of American soft power?

\section{Review of Literature}

This chapter presents previous studies which are relevant to the analysis of the trilogy of Captain America movies. It will start with the explanation of power, followed by the different forms of power. The new face of power will be introduced and a definition will be given. After which, since this research focuses on American soft power through Hollywood superhero movies, this chapter will also review previous studies of popular culture, as the movies themselves are part of the popular culture, and popular culture is one of the most influential ways to produce soft power.

\subsection{What Is Power?}

Before talking about soft power, it is important to know the concept of power. There is a debate among political scientists about the concept of power, as the definitions of power have been defined differently from each researcher's perspective in world politics. Power is the term which is known and recognized by all, but few people understand it. A lot of people have power but the impact of power depends on a relationship between them. Robert Dahl (1957), one of the most famous political scientists, defined 'power' as the relationship between individuals - power exists within the relationship where one may influence another to commit actions they would not otherwise do on their own decision. For example, a policeman, a person with the authoritative power in relation a civilian, an individual who is influenced to obey to said authority. When ordered, for 
example, to park a car for a police search, the civilian naturally obeys. Therefore, in this case the policeman has power over the drivers to control them to go to the direction that he wants. The Cambridge dictionary described the meaning of power as an ability to control people and events. It is the capacity to take actions, the ability to get the outcome that one wants. In addition, the dictionary tells us that power is the capability to affect the behavior of others, or influence others' behaviors to get the outcomes that one wants.

Joseph Nye (2004) defined power in the most general level as "the ability to influence the behavior of others to get the outcomes you want". A person can force someone to do something that one wants by using threats, command, or co-opt. It depends on the context and relationship which power is used. Nye also referred to power as the control of abilities or resources that influence outcomes. A country will be considered as powerful if it has a relatively large population and territory, extensive natural resources, economic strength, military force, and social stability as the United States, China, and Russia, for example. However, having all power resources does not mean that you will get the result that you want. To illustrate, the United States had the advantages over Vietnam in almost every way during the Vietnam war. Nonetheless, having a bigger and stronger U.S army did not mean they could win this war, nor could it prevent its country from atrocious terrorist attacks including $9 / 11$. Having dominant power is one of the desires which a lot of people and nations want to achieve. World politics is an example to illustrate what power is, because many countries race to become world leaders, so they have to compete against each other in every way to accomplish their goals. One of the countries that is well-known and has high influence is the United States of America. They have become the world's most powerful nation after the Allies victory in World War II.

\subsection{A Traditional Form of Power}

The USA and the Allies' victory in the second World War came from the usage of traditional form of power; it was the use of economic and military power and this practice is called hard power. Hard power is used as a tool to influence the behaviors of others to follow what one wants. Hard power is often aggressive and is often shown in the form of politics. The countries that have more power usually use economic sanctions or the military threat to invade those who have less power. The United States is an example of how one uses their hard power to threaten others. The USA used their military ability against the terrorists in the War on Terror after the September 11 incident in 2001. As seen and heard in many international news outlets, the USA sent an army of soldiers to the Middle Eastern countries and ordered economic sanctions with Iraq during Saddam Hussein's regime. The United States has also used sanctions on other Middle Eastern countries such as Syria, Iran, Lebanon, Libya, and Yemen to pressure them (Sanctions Program and Country Information, 2017). Jonas Elmerraji (2010) said that "Economic sanctions are a popular way for large governments to exert their disapproval over one another. While wars are costly - both economically and politically_economic sanctions tend to be somewhat less tangible, at least for the country doing the sanction, but for the country being sanctioned, the results can be enormous and long lasting". Hard power has been a traditional form of a foreign policy tool for a long time, but in the twenty-first century, another kind of power, which has existed in history for a long time but rarely was it publicized, has emerged, been defined, coined and developed further.

\subsection{New Face of Power and Its Resources}

This form of power, which is now widely discussed among political scientists, is named soft power and was firstly labeled so by Joseph Nye in 1989. Nye was aware of the existence of soft power throughout history but explained that even though the concept of soft power is recent, the behavior it denotes is as old as human history (Nye, 2008). Nye (2004) defined soft power as the ability to get what you want through attraction rather than coercion or payments and it arises from the attractiveness of a country's culture, political ideals, and policies. Soft power is more than just persuasion or ability to move people by argument, though that is an important part of it, it is also the ability to attract, and attraction leads to acquiescence. If one can influence without coercion; either to do what one wants or to follow one's lead, no force is necessary (Nye, 2008). Nye (2008) further explained that soft power is one source of influence. It is an attractive power and its resources are the assets that produce such attraction. He stated that soft power may be less relevant than hard power in preventing attacks, policing borders, and protecting allies, but soft power is particularly relevant to the realization of surrounding. Soft power of a country based on three resources which are:

1) The American culture (in places where it is attractive to others)

2) The American political values and (when it is present at home and abroad)

3) The American foreign policies (when they are seen as legitimate and having moral authority)

Soft power is an element of influence. It is formed largely by our own values. These values are shown in culture, 
policies in our own country, and the way we behave internationally (Nye, 2002-2003). Soft power on occasions is difficult to use and it is easy to lose the impact of soft power; if you lose it, it is expensive to regain. However, it is probably a better risk averse option than the use of military or economic power. In order for soft power to be successful, it relies on its credibility. This credibility is damaged beyond repair when governments are seen to use it for propaganda and to manipulate societies, and cultures; propaganda, in its essence, is negative. Nye (2015) stated that the best propaganda is not propaganda. Conversely, soft power is seen as a more positive form and affects others to gain the desired outcome by the cooperation of framing the agenda, positive attraction, and persuasion. To put it simply, hard power is push and soft power is pull (Nye, 2011).

Although the military is mostly associated with hard power, on occasions they also play a role in generating soft power. The military has also arranged joint training, assistance programs, and the exchanging of its officers with other countries during times of peace. In contrast, soft power that the government wields is not at the same level as the hard power they own. This hard power includes resources such as oil and gas, assets such as the armed forces; the latter being strictly governmental (Nye, 2002-2003). Technology has advanced and smart phones change the way people receive information; Governments now use social media to communicate with their people. Therefore, it is easier to create soft power as people have many channels to access soft power.

\subsection{Captain America and His Movies}

Before Captain America became a Hollywood film, he was a fictional superhero appearing in American comic books published by Timely comics, a predecessor of Marvel Comics and was created by the cartoonists Joe Simon and Jack Kirby in the early 1940s during the explosion of World War II in Europe. Captain America was designed as a patriotic super soldier who often fought the Axis powers of World War II, and he can sacrifice himself to preserve his nation. The cover of Captain America \#1 was Steve Rogers punching Hitler in the face and this first comic of Captain America had sold almost one million copies during that time. Captain America was a consciously political creation. It is not just only a traditional type of superhero movie where the story is about the good guys catching the bad guys and the hero saving the world, it also contains a lot of political issues hidden inside the story lines. The popularity of Captain America began to fade in the late 1940s because there were no more Hitlers or Hirohitos to valiantly beat up and at this time the Captain America's story ended for a while. Eventually, Stan Lee, who was working at Atlas Comics at that time, revived Captain America in 1953. Lee realized that the country was shocked by the Korean War and was in need of heroes again, so he reintroduced Captain America (Misiroglu \& Roach, 2004). However, at that time there were no Nazis, instead, Lee created a new villain based on the situation during that time that the U.S. fought against the communist in North Korea. He labeled Captain America as a 'Commie Smasher'. Bellotto (2014) said that Joseph McCarthy, the Republican U.S. Senator of Wisconsin, also used Captain America as a mouthpiece against communists. In the late 1950s early 1960s, superhero comics were in vogue once again so Captain America had a chance to return to the forefront of the comics as a regular old superman who vanquished all evils, regardless of whether it was currently in conflict with the United States. Captain America's reintroduction came in the comic Avenger\#4, when he was discovered in a block of ice, thawed, and then promptly given a leadership position in the Avengers. It is at this point when Captain America became the Cap most audience know today and the one in all those movies (Bellotto, 2014).

Captain America was produced into three of his own movies which are Captain America: The First Avenger (2011), Captain America: The Winter Soldier (2014), and the latest released, Captain America: Civil War (2016). These three movies have made a great amount of money for Marvel between 2011 to 2016 and the money that they made has increased with each new release. As of 2017, Captain America: The First Avenger (2011) is ranked the $306^{\text {th }}$ in all time box office worldwide grosses and it made 370.6 million USD during the time when it was in the cinemas. The sequel Captain America: The Winter Soldier (2014) made 714.3 million USD and it is listed as number 100 in the record. The last one Captain America: Civil War (2016) has made a big jump from $100^{\text {th }}$ to the $22^{\text {nd }}$ and it made 1.153 billion USD (All Time Box Office: Worldwide Grosses, n.d.). The amount of money they have made and the better rankings in the box office worldwide grosses record indicate that the popularity of Captain America character and his movies have augmented since it first released. The Captain America character was formed as a symbol of nationalism and identity and to symbolize everything that is great about the United States so it is interesting to study how the U.S. uses this character and its movies to influence their citizens and people around the world.

Jason Dittmer (2013), an expert on geopolitics and popular culture, called Captain America as a nationalist superhero. He used the term nationalist superhero to identify someone who represents himself or herself as a guardian of a specific nation or state explicitly through his or her name, uniform, and mission. He further explained that Captain America was written as a super-soldier created by the U.S. government and later, he sees 
himself as the living embodiment of the American Dream rather than a tool of the state and when he was added the star-spangled uniform and the name as Captain America it was apparent that he is the representative of the country. The nationalist superhero like Captain America carries an additional burden that other superheroes do not which is the embodiment of the nation-state. The embodiment in the nationalist superhero has implications for the kind of stories that are likely to be told and the way they are likely to be read. Additionally, it is said that Captain America is the archetype of the nationalist superhero even though he was not the first character that was created (Dittmer, 2013). Apart from his name, Captain America, and the national flag costume which are represented through the character, a weapon that he carries, a shield, indicates his association with the American geopolitical script. His shield also has patriotic color; red, white, and blue with the star, as the American national flag and it is a defensive weapon which is different from other superheroes' that are offensive. However, Captain America uses his shield as an offensive weapon when he hurls his shield to his opponents and it bounces back to him. Captain America's shield indicates that America embodies defense rather than offense (Dittmer, 2005, 2013).

Captain America is an example of popular culture's role. He is used as a cultural product that has an ability to vaguely and invisibly connect the political projects of the American nationalism, internal order, and foreign policy through an individual to the scale of the nation (Dittmer, 2005). Captain America's character embodies the American identity and shows the audiences that he is a hero both of, and for, the nation. Furthermore, younger audiences may dream about being Captain America, linking themselves to the nation in their imaginations. His character as an explicit American superhero makes him a representative of the idealized American nation and as a guardian of the American status quo (Dittmer, 2005). Stan Lee, a former writer for Captain America, explained that Captain America represents the best aspect of the USA; courage and honesty (as cited in Dittmer, 2005, p. 629). Moreover, his image and origin reflect the American dream and identity of 1941. A blond-haired, blue-eyed man with his almost obsessively Anglo-American name, Steve Rogers, overcomes his physical weakness to become a proud soldier for his nation and the fact that Captain America has fewer superpowers than other superheroes which turns to be his uniqueness as his real skills rely on his athleticism and his leadership skill. (Dittmer, 2005). Captain America in both movies and comic books show many different aspects to the readers and audiences. Anne Egros (2011) argues that Captain America mirrors the social values and principles that unite Americans such as individualism, idealism, and a can-do attitude. Additionally, he illustrates the importance of freedom, equality, and justice. Mark D. White (2014) also claims that Captain America embodies the distinctive timeless principles of Americans which are freedom, equality and justice; he believes that the American ideals are universal. They do not apply just for Americans but for all people around the world (White, 2014). In conclusion for Captain America's character, it is obvious that he is a symbol of the USA and good aspects of the country, so it makes him interesting to study for this reason.

\section{Theoretical Framework: The American Values}

Culture and values have a strong relationship between each other. They are two of the three resources (the third being policies) used to help one country create soft power. As Nye (2004) stated that culture is a set of values and practices that create meaning for societies. Cultural resources are needed to promote and share a country's values. If a country's values are admired by other countries to the point they are influenced and desire to adopt the country's values, that country may gain influence in world politics as soft power rests on the ability to shape others' preferences. The values that are related to this research are individualism, democracy, liberty, equality, and patriotism.

\subsection{Patriotism}

Patriotism is defined as the love of a country and attachment of national value (as cited in Skitka, 2005, p. 1996). It is an effective attachment of the in-group independent of one's feeling towards the out-group or authorities (Blank \& Schmidt, 2003). Rufus W. Clark (1847), an American pastor and author, wrote in his work 'What is patriotism?' that a person who is a true patriot not only avows to love his country, but is willing and ready to sacrifice his own interests, his ambition, his property, and his life for his nation's good if it is necessary. He uses his powers, judgement, and influence to keep the property and his fellow-citizens lives safe, and contribute to the advancement of the nation virtue, prosperity, and happiness.

\section{Results}

Patriotism is the value that is distinctly demonstrated in Captain America movies; especially through Steve Rogers or his Captain America character. Steve Rogers is a very patriotic man who is willing to sacrifice his life to serve his beloved country. He has a strong passion to become a soldier so he tries to apply for the army many times, even though he is rejected he keeps trying until he reaches his dream. His strong intention to be a soldier 
and serve his country reflects patriotism that he has in himself. After Dr. Erskine finds Rogers, he puts Rogers in a training with other soldiers because Dr. Erskine wants to give Rogers a chance to prove himself that he can be the right subject for the super soldier serum project. In fact, Dr. Erskine has made the decision to choose Rogers as the subject already, however Colonel Philips is unconvinced by Dr. Erskine's decision because he thinks Rogers is too weak to take that duty. So, he takes a hand grenade and throws it at where the new recruits are training, all the soldiers move away quickly but Rogers jumps on top of the grenade covering it with his body. "Get away! Get back!" Rogers shouts and waits for the grenade to go off but nothing happens. This situation shows that Rogers commits an act of self-sacrificing bravery; he is not afraid to sacrifice his life in order to protect other people. Rogers' decision to undergo the super soldier process shows the courage in him as no one knows whether the process will work or not and it also shows that Rogers has a love of his country because he is willing to do whatever it takes to help his country win the war even if it might cost his life if the process goes wrong. Fortunately, the serum works and it turns Rogers into a super soldier. He is on a front page of many newspapers as he rescues a child from the Nazis. Senator Brandt says to Rogers that the enlistment lines have been around the block since his picture hit the newsstands so he promotes Rogers to do a more important job than just being a soldier. Senator Brandt puts Rogers as a performer dressing up like a superhero to sell war bonds to the citizens around the United States. The purpose of his performance is to create patriotism to the citizens and encourage them to support the ongoing war. When citizens have the love of their country, they will support the war by buying the war bonds, and the government will use those bonds to buy bullets, tanks and other weapons in order to fight in the war. Additionally, the song used in the performance, the Star Spangled Man with a Plan, has a main substance to arouse the citizens to see the importance of the war and to visualize how cruel the Axis power is. The performance works very well as the bond sales increase at least ten percent in every state that Rogers visits, as well as the advertisement in the cinema when Rogers goes to see the movie describing what is happening and how important for the citizens to support makes some audiences' eyes full of tears. The advertisement has an objective to activate patriotism in people's minds. Therefore, the feeling and action that the citizens have toward the war by purchasing the war bonds after seeing the performance or feeling supportive after watching the advertisement reflect patriotism that is successfully created in the citizens' minds. Rogers' costume as Captain America demonstrates an attachment of national values as the costume contains the colors of red, white, and blue with the star which are the colors and a symbol of the American flag. Captain America's costume makes him look more patriotic because it is obvious to see him as a representative representing his country. Rogers as Captain America operates the missions to save a lot of people's lives. For example, he leads an attack to stop Schmidt from using weapons of mass destruction on the American cities and he sacrifices his life controlling the burning airplane to land on the Arctic shelf instead of crashing it to the city. Moreover, he has to fight the winter soldier in order to stop HYDRA from launching the Helicarriers which aim to kill innocent people around the world and he almost gets himself killed from participating in that mission. In addition, he has an intention to protect the world's citizens from the other winter soldiers as he thinks that Helmut Zemo will wake them up from the frozen machines. Therefore, he is in a hurry to travel to the HYDRA laboratory in Siberia to stop them; the only worry for him is the safety of the citizens. He does not care if his life will be at risk when he tries to protect his people and his beloved country. Other men such as James Barnes, the Howling Commandos, and males who enlist for the army also show their patriotism. They apply for the army with the same reason; they want to protect their loved ones from danger and serve their country. Captain America is a true patriot, he not only avows to love his country, but he is willing and ready to sacrifice his own interests, his ambition, his property, and his life for his nation's good; if it is necessary. He uses his powers, judgement, and influence to keep the property and his fellow-citizens lives safe, and contribute to the advancement of the nation virtue, prosperity, and happiness (Clark, 1847).

Other than specific scenes, overall, in the Captain America trilogy, it has been evident throughout the films that Captain America is the embodiment of American central values, especially Patriotism. In the first installment of the series, Captain America: The First Avenger, Rogers was eager to become a soldier and serve his country; supporting the war effort as means of Patriotism. Later, his sense of patriotism evolved, becoming a more complex character with his own moral compass after his doubts of the authority in Captain America: The Winter Soldier. His anti-authority and control gave a nuance definition to Patriotism as Rogers backed up his argument on his strict moral code, saving humanity, and not being subjected to political agendas - deeming government agendas to be problematic and deserving distrust. The release of Captain America: The Civil War (2016) was at the time USA was at a political divide - it raised a question of whether superheroes were best being free individuals to serve the people or being agents of the state. Captain America made a point that USA as a country that abandoned civil liberties is not a state that anyone would wholeheartedly serve - and thus Captain America has evolved the definition of Patriotism to grow out of simply serving the state and blind obedient to supervision (Maruo-Schröder, 2018). 


\section{Conclusion}

The trilogy of Captain America is one of the most blatant cases of art imitating life. With the trilogy being the main installment within the Avengers movies series, expanding over six years and accumulating gross revenue of over $\$ 2.2$ billion worldwide (The Numbers, n.d.), shown to more than 4,000 cinemas globally (Captain America, n.d.), the influences of the movies are far-reaching - the plot, the characters, the ideologies, and the messages between the lines are orchestrated for the global audience to take the backseat and viewed the conflicts through American lens. The trilogy, through all it stands for, expanded the American soft power in three fronts; culture, values, and the US policies.

People from all around the world empathize with American perspective through Hollywood movies and mass media it produces and exports over the decades. Superheroes movies are especially powerful due to its entertaining plot, relatable characters, and inspiring heroes. The Captain America trilogy is in itself a symbolic representation of American culture and value. It instills the values of democracy, individualism, and liberty as well as the costumes and American way of life through the scenes and dialogues - all-encompassing schemes represent the identity of the USA (Street, 1997). The character of Captain America is portrayed to be bigger than life; strong and muscular, handsome, patriotic, and most of all, the symbolic hero with the ability to protect everyone from harm, i.e., wars and the enemies in all forms. This character identity creates an unconscious link to the identity of the US; forming a connection between the fantasy and the reality in people's minds. Hours spent in the movies, days after days discussing the movies and moral of the stories online with fellow fans, months enjoying the subculture spiraled out of the films in multiple forms, and over the years, the trilogy captured people's imagination.

The messages on American values, democracy, individuality, liberty, equality, and patriotism, in the trilogy were well integrated. The message on democracy was straight forward; democracy rules the land. The government listens to the will of the people and protection and security of its citizens is a mandate. The clear example is the conflict regarding the Sokovia Accords, the solution to manage the Avengers' operation and limit their authority. Although the message of the necessity of government control is at odds with another American value, individualism, the trilogy still upholds this value throughout the storyline; from Rogers pursuing his dream of serving the army in the first movie to him choosing to operate independently out of his own redefinition of patriotism. Another American value reflected in the trilogy is Liberty. The liberty in thought and discussion as seen through all distinct characters' expressions. The liberty of individuality, every character chose their own destiny and lived out their full identity; Rogers chose to enlist to the army, he chose to stop the super soldier operation, and he chose to reject the Sokovia Accords. The value of Equality or 'equality of opportunity' was demonstrated through the facilitation of individual choices, e.g., Rogers' opportunity to be enlisted and subsequently chosen for the super soldier operation. As for Patriotism, Captain America is the embodiment of American patriotism signifies not only through his name but his willingness to sacrifice his interests, ambitions, and life for his beloved country and people.

The third source of American soft power, policies, is reflected in the symbolic debate over the Sokovia Accords, the conflict between Captain America and Ironman represent conflicting ideologies on the US role in the world stage. Over the period of the trilogy, the US government faced multiple challenges on the global stage and changed its foreign policies accordingly; withdrawing troops from foreign soils, operating drone strikes in its War on Terror, increasing military presence in Eastern Europe and imposed sanctions on Russia as a response to Crimea annexation, and other policies concerning the intervention of the US to promote its value of democracy. The essence of this reality is captured and reimagined on film, represented via the conflict in Captain America: the Civil War, whether the Avengers' role as a global police force is justifiable since the impacts may cause the loss of lives and the fall of state sovereignty. Regardless, through an American centric view presented, the US eventually emerged as the righteous hero.

It is also important to note that the trilogy is not only American centric, it is also white male-centric, imagining Steve Rogers, a handsome and muscular blonde Caucasian man as an embodiment of USA. There are female lead characters and people of different races but they only appeared in supporting roles that cater to the growth and greatness of Captain America and the portrayal of the US in a heroic role.

All in all, these messages exemplify via the trilogy's plots, storylines, scenes, dialogues, and strings of images are strong influences to the global audience's mindset on the US as a country, what it stands for, and the judgement on its actions. The Captain America trilogy undeniably has its fair share in the contribution to American soft power.

\section{References}

Bellotto, A. (2014, April 1). 74 Years of Captain America: A History of Marvel's America-iest Superhero. Retrieved from Film School Rejects 
https://filmschoolrejects.com/74-years-of-captain-america-a-history-of-marvels-america-iest-superhero-9ed 077efb670/

Blank, T., \& Schmidt, P. (2003). National Identity in a United Germany: Nationalism or Patriotism? An Empirical Test with Representative Data. Political Psychology, 24(2), 289-312. https://doi.org/10.1111/0162-895X.00329

Clark, R. W. (1847). What is patriotism? Advocade of Peace (1847-1884), 121-124.

Dahl, R. A. (1957). The Concept of Power. Behavioral Science, 2(3), 201-205. https://doi.org/10.1002/bs.3830020303

Dittmer, J. (2005). Captain America's empire: Reflection on identity, popularculture, and post 9/11 geopolitics. Annal of Association of America Geographers, 95(3), 626-643. https://doi.org/10.1111/j.1467-8306.2005.00478.x

Dittmer, J. (2013). Captain America anf the nationalist superhero: Metaphors, narratives, and geopolitics. Philadelphia: Temple University Press.

Elmerraji, J. (2010, Aprol 8). Countries Sanctioned by The U.S.-And Why. Retrieved from Investopedia https://www.investopedia.com/financial-edge/0410/countries-sanctioned-by-the-u.s.---and-why.aspx

Engros, A. (2011, July 27). Whar can we learn about American Culture from Captin America? Retrieved from Anne Egros, Expat Life, Career, Executive Coach https://zestnzen.wordpress.com/2011/07/27/what-can-we-learn-about-american-culture-from-captain-ameri $\mathrm{ca} /$

Kellner, D. (2010). Cinema Wars: Hollywood film and politics in the Bush-Cheney era. Oxford: Wiley-Blackwell.

Kord, S., \& Krimmer, E. (2013). Contemporary hollywood masculinities: Gender, genre, and politics.

Maruo-Schröder, N. (2018). "Justice Has a Bad Side": Figurations of Law and Justice in 21st-Century Superhero Movies. European Journal of American Studies, 13(4). https://doi.org/10.4000/ejas.13817

Nye, J. (1990). Soft power. Foreign Policy, 153-171. https://doi.org/10.2307/1148580

Nye, J. (2004). Soft power and American foreign policy. Political Science Quarterly, 119(2), 255-270. https://doi.org/10.2307/20202345

Redmond, P. (2017). The historical roots of CIA-Hollywood propaganda. The American Journal of Economics and Sociology, 76(2), 280-310. https://doi.org/10.1111/ajes.12177

Robb, D. L. (2004). Operation Hollywood: How the Pentagon shapes and cencors the movies. New York: Pometheus.

Secker, T., \& Alford, M. (2017). Why are the Pentagon and the CIA in Hollywood? The American Journal of Economics and Sociology, 76(2), 381-404. https://doi.org/10.1111/ajes.12180

Skitka, L. J. (2005). Patriotism or nationalism? Understanding post-September 11, 2001, flag-display behavior 1. $\begin{array}{lllll}\text { Journal of Applied } & \text { Social Psychology, } & \text { 35(10), }\end{array}$ https://doi.org/10.1111/j.1559-1816.2005.tb02206.x

Street, J. (1997). Politics and popular culture. Oxford: Blackwell.

Tarabay, J. (2014, July 29). Hollywood and the Pentagon: A relationship of mutual exploitation. Retrieved from America

Aljazeera

http://america.aljazeera.com/articles/2014/7/29/hollywood-and-thepentagonarelationshipofmutualexploitati on.html

U.S. Department of the Treasury. (2017, April 28). Sanctions Programs and Country Information. Retrieved from https://www.treasury.gov/resource-center/sanctions/programs/pages/programs.aspx

White, M. D. (2014). The Virtues of Captain America: Modern-day lessons on character from World War II superhero. West Sussex: Wiley-Blackwell. https://doi.org/10.1002/9781118619353

\section{Copyrights}

Copyright for this article is retained by the author, with first publication rights granted to the journal.

This is an open-access article distributed under the terms and conditions of the Creative Commons Attribution license (http://creativecommons.org/licenses/by/4.0/). 